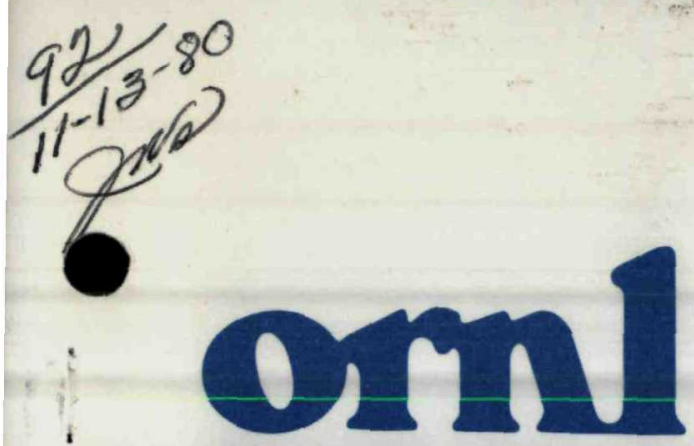

OAK

RIDGE NATIONAL LABORATORY

UNION CARBide

\title{
The Polymerization of Pu(IV) in Aqueous Nitric Acid Solutions
}

\author{
L. M. Toth \\ H. A. Friedman \\ M. M. Osborne
}

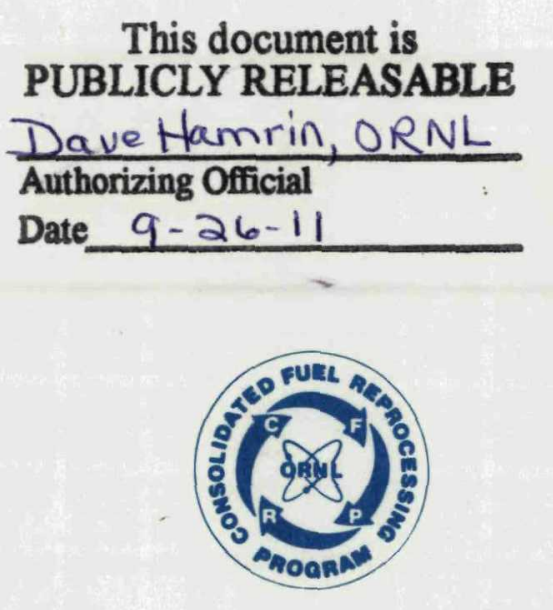

\section{OPERATED BY}

UNION CARBIDE CORPORATION FOR THE UNITED STATES DEPARTMENT OF ENERGY 
Printed in the United States of America. Available from

the Department of Energy

Technical Information Center

P.O. Box 62, Oak Ridge, Tennessee 37830

This report was prepared as an account of work sponsored by an agency of the United States Government. Neither the United States Government nor any agency thereof, nor any of their employees, makes any warranty, express or implied, or assumes any legal liability or responsibility for the accuracy, completeness, or usefulness of any information, apparatus, product, or process disclosed, or represents that its use would not infringe privately owned rights. Reference herein to any specific commercial product, process, or service by trade name, trademark, manufacturer, or otherwise, does not necessarily constitute or imply its endorsement, recommendation, or favoring by the United States Government or any agency thereof. The views and opinions of authors expressed herein do not necessarily state or reflect those of the United States Government or any agency thereof. 


\section{DISCLAIMER}

This report was prepared as an account of work sponsored by an agency of the United States Government. Neither the United States Government nor any agency Thereof, nor any of their employees, makes any warranty, express or implied, or assumes any legal liability or responsibility for the accuracy, completeness, or usefulness of any information, apparatus, product, or process disclosed, or represents that its use would not infringe privately owned rights. Reference herein to any specific commercial product, process, or service by trade name, trademark, manufacturer, or otherwise does not necessarily constitute or imply its endorsement, recommendation, or favoring by the United States Government or any agency thereof. The views and opinions of authors expressed herein do not necessarily state or reflect those of the United States Government or any agency thereof. 


\section{DISCLAIMER}

Portions of this document may be illegible in electronic image products. Images are produced from the best available original document. 
ORNL/TM-7180

Dist. Category UC-86

(Applied)

Contract No. W-7405-eng-26

Consolidated Fuel Reprocessing Program

THE POLYMERIZATION OF Pu(IV) IN AQUEOUS NITRIC ACID SOLUTIONS

L. M. Toth

H. A. Friedman

M. M. Osborne

Chemical Technology Division

Date Published: October 1980

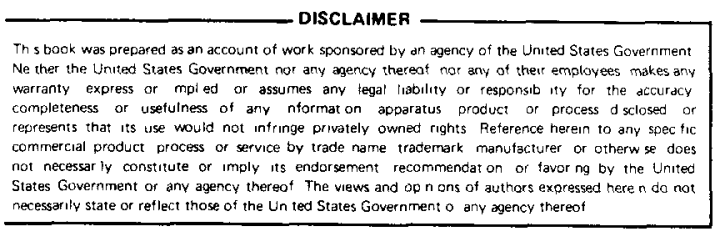

NOTICE This document contains information of a preliminary nature It is subject to revision or correction and therefore does not represent a final report.

\footnotetext{
OAK RIDGE NATIONAL LABORATORY

Oak Ridge, Tennessee 37830

operated by

UNION CARBIDE CORPORATION

for the

DEPARTMENT OF ENERGY
}

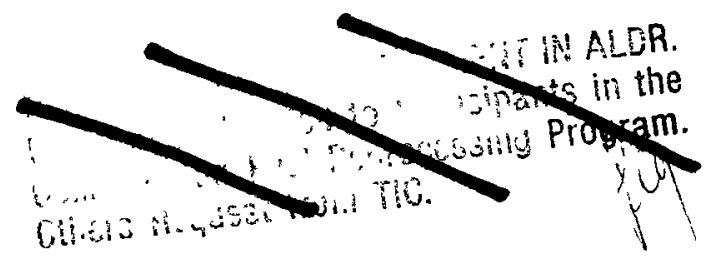


-
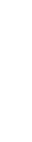
CONTENTS

$\underline{\text { Page }}$

ABSTRACT . . . . . . . . . . . . . . . . . 1

1. INTRODUCTION . . . . . . . . . . . . . . . 1

2. PREVIOUS WORK .................. . 3

3. EXPERIMENTAL PROCEDURE . . . . . . . . . . . . . 4

3.1 Acid Determinations . . . . . . . . 5

3.2 Plutonium Reagent ............ 5

3.3 Uranium Reagent. . . . . . . . . . . . 6

3.4 Absorption Spectra............. 6

3.5 Sample Preparation . . . . . . . . . . 9

3.6 Typical Procedure . . . . . . . . . . . . 10

3.7 Measurement of $\mathrm{UO}_{2}^{2+}$ Uptake by Polymer . . . . 10

4. RESULTS AND DISCUSSION .............. 11

4.1 Reference Solution .............. 11

4.2 General Polymerization Characteristics..... . 11

4.3 Induction Period ............. 13

4.4 Uranyl Nitrate Effect .............. . . . 14

4.5 Reproducibility of Data . . . . . . . . . 21

4.6 Dilution Effects.............. 24

4.7 Plutonium Concentration Effect........ . 25

5. CONCLUSIONS . . . . . . . . . . . . . . . . 29

6. REFERENCES. . . . . . . . . . . . . . . 31

Appendix. Molar Extinction Coefficients for P1utonium Species at $50^{\circ} \mathrm{C}$. . . . . . . . . . . 33 
ORNL/TM-71 80

Dist. Category UC -86

(Applied)

THE POLYMERIZATION OF PU(IV) IN AQUEOUS NITRIC ACID SOLUTIONS

L. M. Toth

H. A. Friedman

M. M. Osborne

\begin{abstract}
The polymerization of $\mathrm{Pu}$ (IV) in aqueous nitric acid solutions has been studied spectrophotometrically both to establish the influence of large $\mathrm{UO}_{2}\left(\mathrm{NO}_{3}\right)_{2}$ concentrations on the polymerization rates and, more generally, to review the influence of the major parameters on the polymer reaction. Typically, experiments have been performed at $50^{\circ} \mathrm{C}$ and with $0.05 \mathrm{M} \mathrm{Pu}$ in nitric acid solutions that vary in acidity from 0.07 to $0.4 \overline{\mathrm{M}}$.

An induction period usually precedes the polymer growth stage during which time nucleation of primary hydrolysis products occurs. Uranyl nitrate retards the polymerization reaction by approximately $35 \%$ in spite of the counteracting influence of the nitrate ions associated with this solute. The rate of polymer formation, expressed as $d$ (percent polymer)/dt, has been shown to depend on the total plutonium concentration in reactions where the $\mathrm{Pu}(\mathrm{IV})$ concentration remained constant; and it is therefore suggested that the polymer reaction rate is not first order with respect to the concentration of plutonium as was previously thought.

It has been shown further that accurate acid determinations on stock reagents are essential in order to obtain reliable polymerization experiments. Satisfactory procedures for these analyses did not exist, so appropriate modifications to the iodate precipitation methods were developed. The most ideal plutonium reagent material has been shown to be crystalline $\mathrm{Pu}$ (IV) nitrate because it can be added directly to acid solutions without the occurrence of unintentional hydrolysis reactions.
\end{abstract}

\title{
INTRODUCTION
}

The hydrolysis and polymerization of $\mathrm{Pu}$ (IV) has attracted research interests for several decades, beginning with the first fundamental observations on the hydrolysis behavior of this cation ${ }^{1-6}$ and later 
proceeding to practical implications of such chemistry in fuel reprocessing. Two of the frequently cited applied reports have been those by Brunstad ${ }^{7}$ and Schuelein ${ }^{8}$ in which the extent and/or rate of $\mathrm{Pu}(\mathrm{IV})$ polymer formation as a function of $[\mathrm{Pu}], *\left[\mathrm{HNO}_{3}\right]$, and temperature have been reported.

It might seem redundant that another report on the subject of the practical behavior of $\mathrm{Pu}(\mathrm{IV})$ hydrous polymer should appear especially since the method of investigation (spectrophotometry) was essentially identical to the one used in the previous studies; but considering the changing restrictions on plutonium release in the environment along with the modifications in process flow sheets, a continuing interest in this problem is necessary to keep pace with both the engineering developments and the regulatory requirements.

Since coprocessing of uranium along with plutonium seems to be the currently acceptable method of reprocessing reactor fuel elements, large amounts of uranium, as $\mathrm{UO}_{2}{ }^{2+}$, will accompany plutonium in a nitric acid process stream. Some uncertainty has remained about the hydrolytic behavior of $\mathrm{Pu}(\mathrm{IV})$ in the presence of large concentrations of uranyl ion; therefore, the initial intent of this work was to assess the influence of $\mathrm{UO}_{2}{ }^{2+}$ on the plutonium polymerization chemistry as it had been described for pure solutions. The general nature of the $\mathrm{UO}_{2}{ }^{2+}$ influence has been identified and will be described here.

During this investigation other practical aspects of $\mathrm{Pu}(\mathrm{IV})$ polymer chemistry were also observed, and opportunities for refinement of our present understanding were noted. These will be discussed in some detail because they are integrally tied to $\mathrm{Pu}$ (IV) hydrolytic behavior. The work is not yet complete, and this report is interim in nature. More work must be done using high concentrations (0.1-0.5 $\mathrm{Mu}$ ) and temperatures $\left(50-100^{\circ} \mathrm{C}\right)$ because it is here that the process chemistry becomes most unpredictable.

A review of two of the most frequently cited studies on $\mathrm{Pu}$ (IV) polymer chemistry as applied to fuel reprocessing conditions precedes the presentation of the current results in an effort to "set the stage." It is especially appropriate here because the experimental

approach - absorption spectrophotometry - is common to both the past and current efforts.

*Square brackets, [ ], will be used throughout this reprot to denote "concentration of" the enclosed species. 


\section{PREVIOUS WORK}

One of the most frequently cited articles on the behavior of Pu(IV) hydrous polymers is the 1957 report of Brunstad. 7 Largely from this work has resulted the general understanding that the rate of polymer formation increases with increasing [Pu(IV)], increasing temperature, and decreasing acidity. Furthermore, from Brunstad's Fig. 3, it is evident that no polymer would precipitate from $\mathrm{Pu}(\mathrm{IV})$ solutions with $\left[\mathrm{HNO}_{3}\right]$ greater than $0.3 \mathrm{M}$ at $25^{\circ} \mathrm{C}$; but here the message becomes ambiguous because little distinction was noted between colloidal polymer formation (which would remain suspended) and actual precipitation of polymer. Many of the conclusions about the rates of polymer formation are inferred since only one polymer concentration was spectrophotometrically determined (at $10 \mathrm{~min}$ ) and never thereafter.

Another problem Brunstad had which severely limits the usefulness of his data was his usage of the oxalate method for acid determinations of the solutions containing plutonium ions (see Sect. 3.1 for an assessment of problems associated with acid determinations in solutions containing large amounts of plutonium). Our findings have shown that there can be no certainty of the acid values when measured by the oxalate method.

Finally, Brunstad assumed that the precipitation (and polymerization) reactions had equilibrated or gone to completion after four days (cf. p. 5 of ref. 5), and consequently, the measured acidity of the supernatant liquid represented that "necessary to stabilize the plutonium found in the supernatant." The plutonium concentration of the supernatant was determined by counting methods at that point and could not, therefore, distinguish between $\mathrm{Pu}(\mathrm{IV})$ ions in solution or suspended colloidal polymer. Experience has shown that polymer formation and precipitation continues irreversibly ${ }^{2}$ over a period of days, weeks, and even months. A sampling after 4 days, even if properly done with an acceptable analytical procedure for acid, could represent only an intermediate situation and not that point where plutonium had been stabilized in solution.

Although Schuelein's work ${ }^{8}$ is more recent, it still suffers from many of the same problems which Brunstad experienced. Notably, the oxalate procedure was again used for acid determinations so one must expect much uncertainty in the aid values which are reported. In 
addition, experimental solutions were prepared by water dilutions of concentrated plutonium stock solutions without regard for any polymer that may have been initiated during the operation. Although consistent results might be obtained with such a procedure, the rates of polymer formation will of ten be increased (see Sect. 4.6) as a result of diluting a concentrated plutonium stock solution with water or dilute acid. Finally, it is doubtful that Schuelein's spectral analysis was of quantitative value since he never presented any of his own spectra. (His Figs. 2 and 3 are reproductions of Fig. 1 in ref. 4 and Fig. 2 in ref. 9 respectively.)

Taking the foregoing review into consideration, it is very doubtful that reliable data exist for plutonium polymerization rates in solutions greater than $0.1 \underline{M}$ Pu. If similar reports become available, they should be evaluated along the same lines as used here. Nevertheless, the fundamental studies ${ }^{1-6}$ appear valid with regard to the considerations discussed here and are therefore the only real basis for the generalizations in the opening paragraph of this section. Qualitatively, trends in the polymerization reaction are explainable, but the quantitative parameters describing polymer formation are still undefined. It is intended that the current work will eventually provide these data.

\section{EXPERIMENTAL PROCEDURE}

In many respects, our original procedure was similar to that used by previous workers. Nitric acid and plutonium concentrations were measured by the Analytical Chemistry Division using the oxalate and counting methods respectively. Plutonium stock solutions of about $0.7 \mathrm{M}^{\mathrm{HNO}_{3}}$ and $0.35 \mathrm{M}$ Pu were diluted with appropriate amounts of dilute acid, water, or $\mathrm{UO}_{2}\left(\mathrm{NO}_{3}\right)_{2}$ stock to produce sample solutions, which were loaded into water-jacketed optical cuvettes for absorption spectral analysis during polymer growth. The 400-nm region of the spectrum was monitored throughout the experiment for polymer (usually until about $20 \%$ of the Pu had polymerized) along with bands at 600, 475.7, 1130, and $951 \mathrm{~nm}$ for $\mathrm{Pu}(\mathrm{III}),(\mathrm{IV}),(\mathrm{V})$, and (VI) respectively. From calibration curves for the species in solution, the concentration and percentage of polymer could be determined. For most of the work reported here, the detection limit for polymer was $1 \%$ of the total plutonium concentration (e.g., for a $0.05 \underline{\mathrm{M}} \mathrm{Pu}$ sample, $0.0005 \mathrm{M} \mathrm{Pu}$ polymer was detectable in a $1-\mathrm{cm} \mathrm{ce} 11$ ). 
As the work progressed, however, problems developed with the traditionally accepted procedure, which prompted several changes. The modifications in the procedure are described below. Furthermore, additional justification for these changes is given in Sect. 4 because they have such an important bearing on the validity of any such study.

\subsection{Acid Determinations}

Evidence that concentrated Pu(IV) hydrolyzed during oxalate and iodate acid determination procedures required the development of a modified iodate precipitation method. Three milliliters of the $\mathrm{pH} 4.3$ adjusted $\mathrm{KIO}_{3}$ reagent (see ref. 10 for details of original procedure) was further acidified by adding $0.5 \mathrm{ml}$ of $0.988 \mathrm{M} \mathrm{HNO}_{3}$. To this vigorously stirred solution was added a $0.100-$ or $0.200-\mathrm{ml}$ aliquant of concentrated plutonium stock solution. It was at this time that most of the $\mathrm{Pu}\left(\mathrm{IO}_{3}\right)_{4}$ precipitate formed. The mixture was transferred into the remaining $47 \mathrm{ml}$ of $\mathrm{KIO}_{3}$ solution to precipitate any remaining traces of $\mathrm{Pu}(\mathrm{IV})$. From this point on, the original procedure was followed. This modified procedure prevented $\mathrm{Pu}(\mathrm{IV})$ polymerization during the dilution steps of the original procedure.

\section{2 Plutonium Reagent}

The occurrence of significant errors during acid determinations and polymerization rate experiments using concentrated $(\sim 1 \underline{M})$ reagent solutions indicated that dilution of these stock solutions to $<0.3 \mathrm{M}$ $\mathrm{HNO}_{3}$ content was impossible without the accompanying initiation of hydrolysis reactions. Therefore, reagent $\mathrm{Pu}\left(\mathrm{NO}_{3}\right)_{4} \cdot \underline{x H}_{2} \mathrm{O}$ crystals were sought which could be simply dissolved in a selected acid solution. This material was prepared by purging the $0.35 \mathrm{M}$ Pu stock solutions to dryness with nitrogen gas and storing the hygroscopic material in a sealed bottle. The occluded acid in the crystals was determined by first dissolving a weighed quantity $(\sim 0.3 \mathrm{~g})$ in $1 \mathrm{ml}$ of $1.0 \mathrm{~N} \mathrm{HNO}_{3}$ and then using the modified iodate precipitation method to determine total acid. The plutonium content was determined by measuring the absorption spectrum of a similar solution and using Beer's Law to compute the concentration. This was superior to analytical counting methods, which invariably gave unacceptable precision. The plutonium and nitric acid contents of a 
typical crystal batch were found by these methods to be 1.724 and 0.744 meq/g respectively. The value of $x$ in the above crystal formula was found to be 3.6. During these dissolution exercises, care was taken to weigh both crystals and acid and to measure the final volume in case nonideal mixing conditions occurred.

An individually weighed quantity of the crystalline reagent was then dissolved in dilute $\mathrm{HNO}_{3}$ at $0^{\circ} \mathrm{C}$ (to minimize any chance of hydrolysis due to the heat of solution) and used immediately afterwards for a typical polymerization experiment.

\subsection{Uranium Reagent}

As with plutonium, uranium additions were originally made from locally obtained reagent solutions. Uncertainties in the acid content of these solutions were impossible to eliminate by standard analytical techniques so $\mathrm{UO}_{2}\left(\mathrm{NO}_{3}\right)_{2} \cdot 6 \mathrm{H}_{2} \mathrm{O}$ reagent crystals, with no deficient or occluded acid, were grown. These were prepared by dissolving $\mathrm{UO}_{3}$ in concentrated $\mathrm{HNO}_{3}$ to make a final solution, after dilution, of 2.5 to 3.0 $\underline{\mathrm{M}} \mathrm{UO}_{2}\left(\mathrm{NO}_{3}\right)_{2}$ in $1 \mathrm{MHN}_{3}$. This solution was evaporated in a desiccator containing $\mathrm{P}_{2} \mathrm{O}_{5}$, and crystalline $\mathrm{UO}_{2}\left(\mathrm{NO}_{3}\right)_{2} \cdot 6 \mathrm{H}_{2} \mathrm{O}$ was separated periodically by filtration. Several batches of these crystals were then collected and recrystallized from a water solution by use of the same procedure. The 1- to 2-cm-diam crystals were then stored in a desiccator over sulfuric acid solution ( $\mathrm{sp} g r=1.35)$ to maintain the hexahydrate form. 11 A weighed quantity of these crystals was then dissolved in water to produce a reagent solution that could be used for subsequent sample preparations.

\subsection{Absorption Spectra}

Absorption spectra were measured in 0.1 - to $1.0-\mathrm{cm}$ optical silica cuvettes over the $400-$ to $1300-\mathrm{nm}$ interval. Cary $14 \mathrm{H}$ and $17 \mathrm{H}$ recording spectrophotometers were used to record the plutonium spectra while the samples remained within a special appendage on a glove box (Fig. 1). These large-sample-compartment spectrophotometers are convenient for this purpose because they are less subject to contamination and provide ample space for rockers, water jackets, etc. A photograph of the cell in the thermostated rocker assembly is shown in Fig. 2 . The various plutonium species were monftored at the several wavelengths indicated in the opening paragraph of this section. It was sometimes necessary to solve Beer's Law simultaneous equations ${ }^{4}$ to obtain the concentrations of 


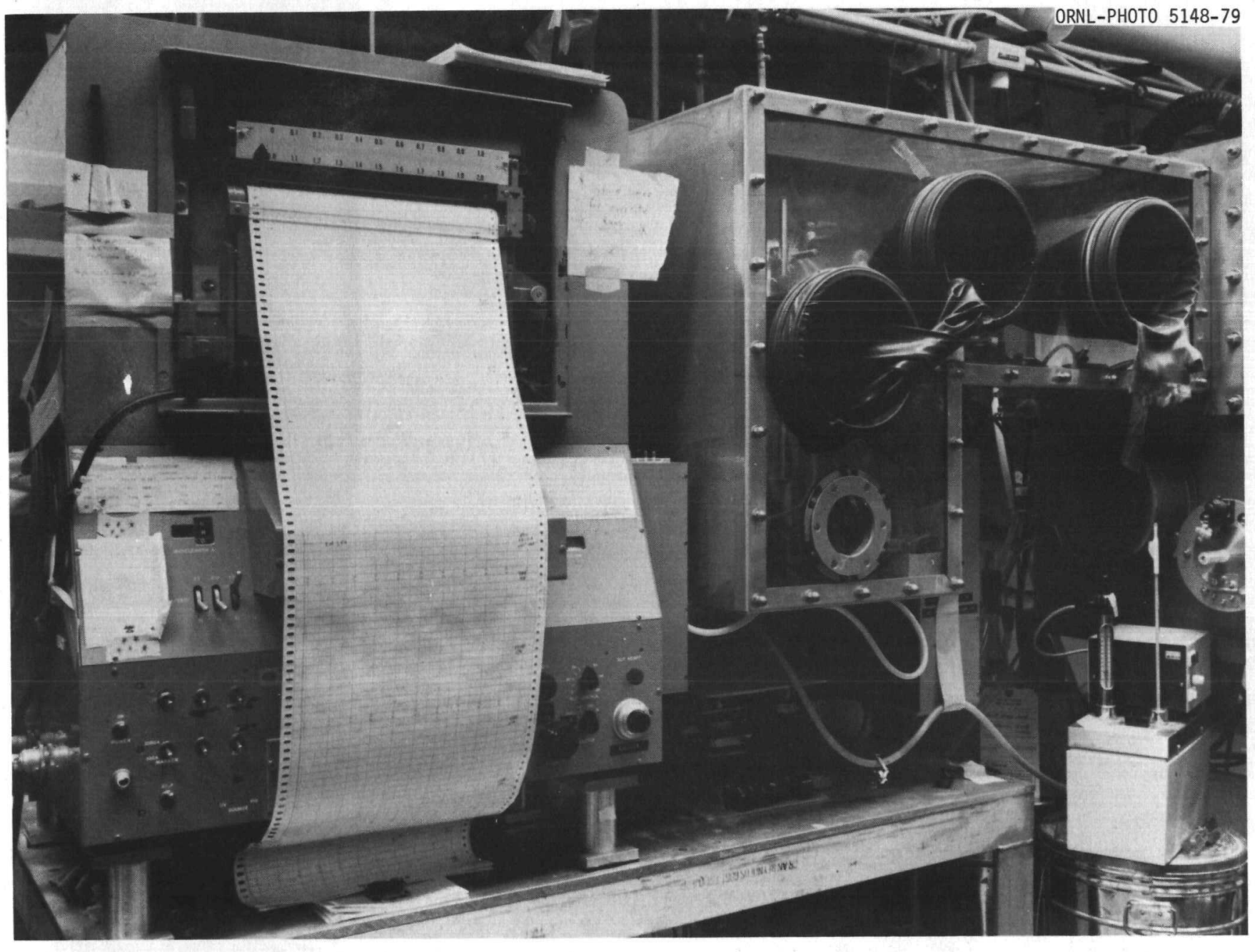

Fig. 1. Overview of experimental apparatus showing Cary $14 \mathrm{H}$ recording spectrophotometer with alpha-box appendage positioned in the optical path of the sample beam. Appendage is attached to left side of alpha box at the right extreme of the photograph. 


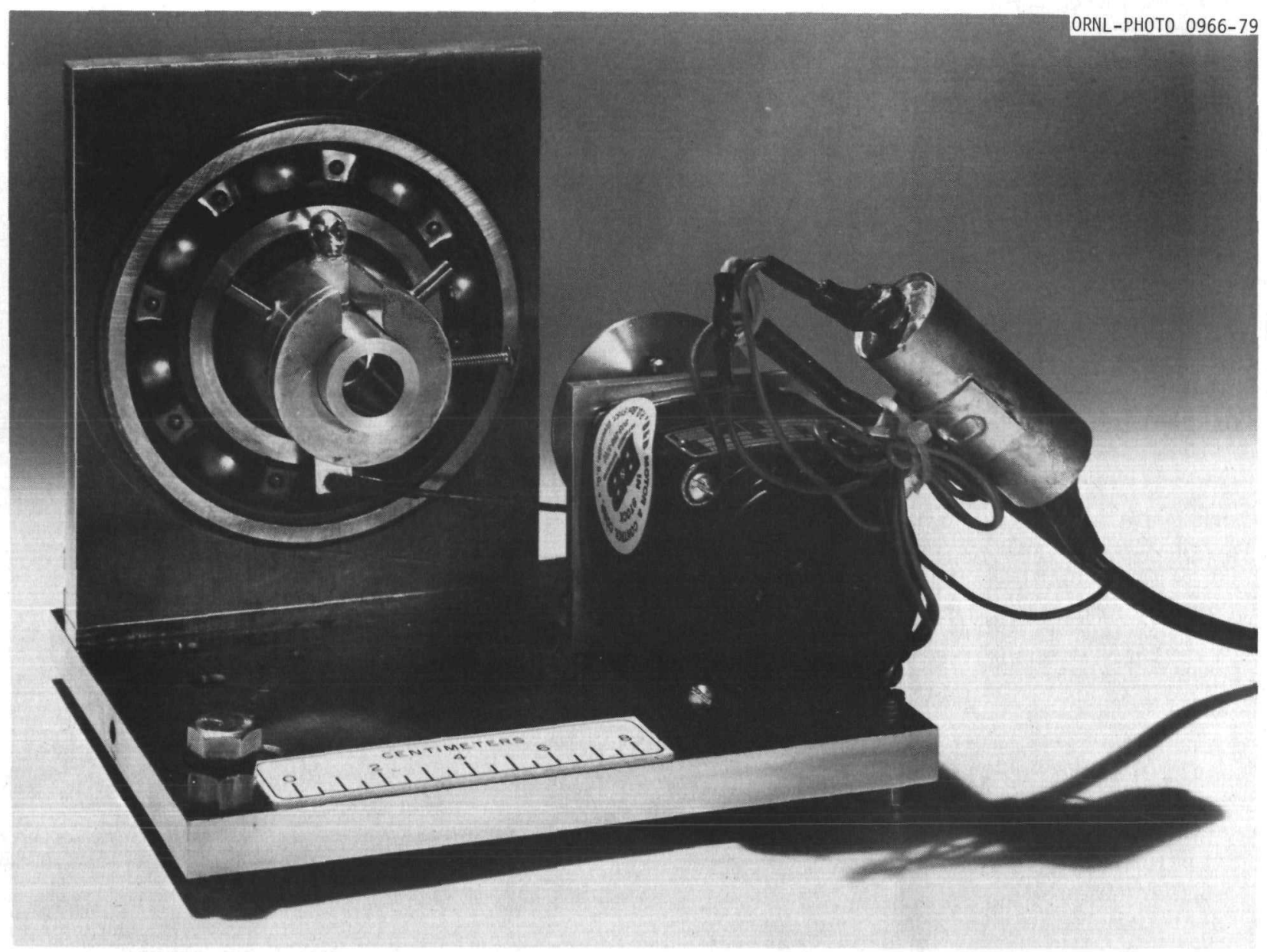

Fig. 2. Sample optical cell, thermostated jacket, and rocker system. Only the ground glass top of the cell is visible in the thermostated jacket. A large wheel bearing forms the support for the cell and jacket assembly and provides rotational freedom about the optical axis of the cell. A rocking motion to the cell is imparted by the driver arm attached to the bottom of the cel1-jacket assemb1y. 
individual species because all of these interfered to some extent at every wavelength.

Although many spectra of plutonium species have been presented in past years, there is no complete set that will enable a satisfactorily quantitative determination of all five plutonium species from spectral measurements followed by solution of simultaneous equations. Costanzo et a1. 4 came closest to this but did not have sufficient data, especially for $\mathrm{Pu}(\mathrm{IV})$ at low acid and high temperature, to permit our quantitative mesurements. Therefore, calibration spectra for the plutonium species have been measured over the range 400 to $1300 \mathrm{~nm}$, at 22 to $50^{\circ} \mathrm{C}$. These are still undergoing computer refinements and will be presented in a later report.

The data presented in this report were obtained by measuring the change in absorbance at $400 \mathrm{~nm}$, subtracting interfering contributions from other species when necessary, and calculating the polymer concentration by use of Beer's Law. The value for $e_{400 \mathrm{~nm}}^{\text {polymer }}=150 \mathrm{~L} \cdot \mathrm{mol}{ }^{-1} \cdot \mathrm{cm}^{-1}$ was found to be insensitive to temperature and acid changes. Typically, 0.5-cm pathlength cells were used for the $0.05 \mathrm{M} \mathrm{Pu}$ solutions, but the pathlength was varied from 0.1 to $1.0 \mathrm{~cm}$ depending on the particular [Pu] under investigation.

\subsection{Sample Preparation}

During the early stages of this work, a simple, conventional dilution appeared to be an acceptable procedure for preparing samples. However, it soon became evident that no matter how much care was taken, such dilutions produced consistently faster rates of polymerization than when stock $\mathrm{Pu}\left(\mathrm{NO}_{3}\right)_{4} \cdot 3 \cdot 6 \mathrm{H}_{2} \mathrm{O}$ crystals were dissolved in $\mathrm{HNO}_{3}$ solution of the desired acidity. Ultimately, both of these procedures were used because the former was significant for comparison with earlier work and the latter represented the ultimate lower limits in $\mathrm{Pu}(\mathrm{IV})$ polymerization rates for a given set of acid and plutonium concentration parameters.

In the first approach, dilutions were made by very slow additions of acid solution, other reagents, or water to a vigorously stirred aliquant of $0.35 \mathrm{M}$ Pu stock reagent containing approximately $0.7 \mathrm{M}$ $\mathrm{HNO}_{3}$. In the refined procedure which eliminated the dilution uncertainties, crystals of $\mathrm{Pu}\left(\mathrm{NO}_{3}\right)_{4} 3.6 \mathrm{H}_{2} \mathrm{O}$ were dissolved in dilute acid of specific concentration for the requirements of the experiment. The dissolution was performed at $0^{\circ} \mathrm{C}$ to minimize the chances of hydrolysis, and all of the solution was used immediately afterwards. 


\subsection{Typica1 Procedure}

Approximately $2 \mathrm{~cm}^{3}$ of sample was loaded into an optical cell whose pathlength had been chosen so that the 476-nm band of $\mathrm{Pu}$ (IV) fell within 0.5 and 1.5 absorbance units. The cell was heated to the temperature at which the $\mathrm{Pu}(\mathrm{IV})$ polymerization reaction would be studied in a thermostated cell rocker assembly that also provided constant agitation of the solution. Temperatures usually equilibrated within $15 \mathrm{~min}$; and because most of the reactions took several hours and followed a prolonged induction period (see Sect. 4.3), little information was lost during these initial moments. A survey scan of the solution was measured from 1300 to $400 \mathrm{~nm}$, and then the spectrometer was left at $400 \mathrm{~nm}$ to monitor any increase in absorbance due to Pu(IV) polymer. Periodically, though, scans over the above wavelength interval were made to keep track of the other plutonium species in solution. The frequency of these scans was dictated by the rate at which the chemistry of the solution changed.

The growth of the $400-\mathrm{nm}$ band was usually followed until at least $10 \%$ of the total plutonium had been converted to polymer. The exception to this occurred at high acid concentrations $\left(>0.13 \mathrm{M} \mathrm{HNO}_{3}\right)$, where only very little polymer formed after many hours' reaction. These extremely slow reactions fit so well with the trends established by the faster reactions that there would be little gain in extending the reactions beyond a few days. Seldom were the polymerization reactions extended to the point where a precipitate actually appeared; data were considered only as long as the polymer remained dispersed in the aqueous phase as a sol. Beyond this point, light scatter from suspended polymer aggregates nullified the usefulness of the absorption spectrophotometric method for polymmer concentration determination.

\section{7 Measurement of $\mathrm{UO}_{2}{ }^{2+}$ Uptake by Polymer}

Test and control solutions were prepared. Both contained $0.05 \mathrm{M}$ $\mathrm{Pu}$ (IV) in $0.117 \mathrm{MNO}_{3}$, but only the test solution contained $0.5 \underline{\mathrm{M}}$ $\mathrm{UO}_{2}\left(\mathrm{NO}_{3}\right)_{2}$. The solutions were held at $75^{\circ} \mathrm{C}$ for two days, cooled to $20^{\circ} \mathrm{C}$, and the polmer precipitated by adding enough crystalline $\mathrm{NaNO}_{3}$ to make the solutions $1 \underline{\mathrm{M}}$. At this point, the control solution 
was made $0.5 \underline{\mathrm{M}}$ in $\mathrm{UO}_{2}\left(\mathrm{NO}_{3}\right)_{2}$ to make its composition identical to that of the test solution. The solutions were filtered, washed two times with $1 \underline{\mathrm{M}} \mathrm{NaNO}_{3}$, and redispersed in $1 \underline{\mathrm{M}} \mathrm{HNO}_{3}$ solution. Analyses were requested for total plutonium and uranium in the sample, and the values reported in Sect. 4 represent those expressed as $100 \% \mathrm{x} \mathrm{U/(U}+\mathrm{Pu})$.

\section{RESULTS AND DISCUSSION}

\subsection{Reference Solution}

The typical reference solution for our study was $0.05 \underline{\mathrm{M}}$ (12 g/liter) $\mathrm{Pu}_{\mathrm{T}}$ at $0.11 \mathrm{M}^{\mathrm{HNO}}{ }_{3}$. (The solution was originally prepared as $\mathrm{Pu}(\mathrm{IV})$, but with some disproportionation at this $\left[\mathrm{HNO}_{3}\right]$, a distribution of species occurred.) This rather arbitrary selection provided a reference point with which other data could be compared. Considerable effort was made to obtain consistency in all the data, and this reference served as a convenient standard of comparison because when heated to $50^{\circ} \mathrm{C}$, it showed approximately $20 \%$ polymerization in $2 \mathrm{~h}$ - that is, it provided a simple one-day test.

\subsection{General Polymerization Characteristics}

Al1 previous polymerization studies 7,8 either used low-sensitivity analyses (detection limits for polymer were $10 \%$ of the total $\mathrm{Pu}$ ) or operated under conditions of such low acid concentration that the initial stages of the polymer reaction were not detected. 4 However, when reaction parameters are chosen so that the polymerization halftime is about 0.5 day and the detection is sensitive enough to identify the first few percent of polymer (expressed as 100\%([polymer]/total [Pu])) that forms, an interesting characteristic of the reaction appears. This is shown in Fig. 3, where the percent polymer is plotted as a function of time for solutions at $50^{\circ} \mathrm{C}$ containing $0.05 \mathrm{M} \mathrm{Pu}, 0.5 \underline{\mathrm{M}}$ $\mathrm{UO}_{2}\left(\mathrm{NO}_{3}\right)_{2}$, and with varying concentrations of $\mathrm{HNO}_{3}$. The reference solution as defined above is shown at $0.11 \mathrm{M} \mathrm{HNO}_{3}$, along with other solutions whose $\left[\mathrm{HNO}_{3}\right]$ are given.

The importance of accurate acid analyses is seen by the effect that $10 \%$ changes in acid concentration have on the polymerization rates. The only reliable approach to acid determinations was that 
TRVL - SU:G $79-20592$

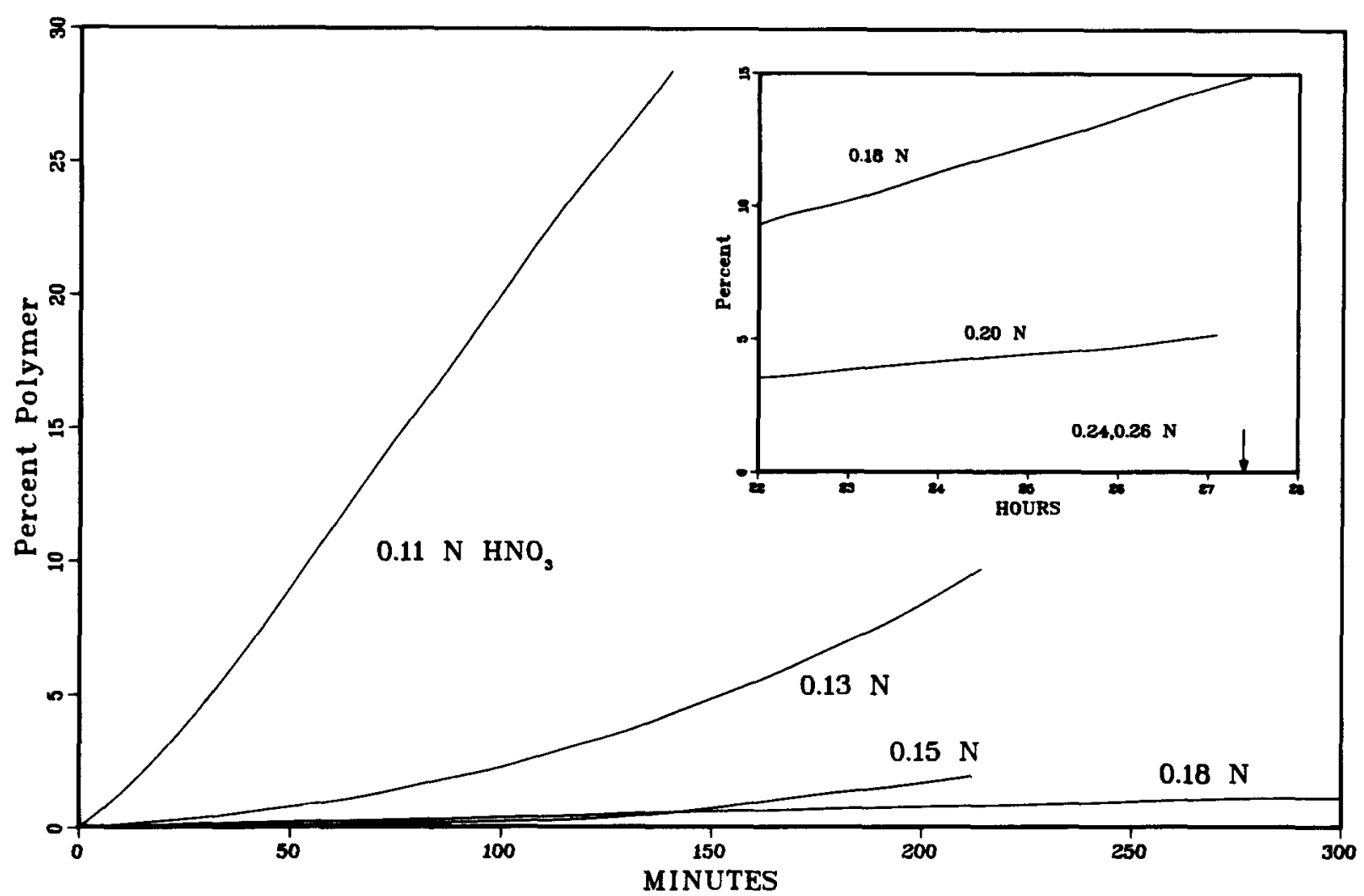

Fig. 3. Percent Pu(IV) polymer as a function of time for $0.05 \mathrm{M}$ $\mathrm{Pu}$ solutions containing $0.5 \mathrm{M} \mathrm{UO}_{2}\left(\mathrm{NO}_{3}\right)_{2}$ at $50^{\circ} \mathrm{C}$. Nitric acid concentrations for each solution are indicated. Percent polymer $=$ 100 ([polymer]/[total Pu]). 
described in Sect. 3, and the most reliable time at which to make this determination on the reagent solutions was prior to sample preparation. Consequently, the acid values indicated in Fig. 3 are for makeup concentrations. They do not include the acid formed from either the disproportionation or hydrolysis reactions that follow; they merely represent the sum of the acid content of the stock reagents and the acid added to the solution during the preparation of the sample. Because the uncertainty in acid determinations for plutonium solutions with $<1 \mathrm{M} \mathrm{H}^{+}$is approximately $10 \%$, the effects shown here would be great1y masked.

However, the combination of very-low-acid reagent plutonium crystals with an uncertainty in acid content of $\pm 5 \%, \mathrm{UO}_{2}\left(\mathrm{NO}_{3}\right)_{2} \cdot 6 \mathrm{H}_{2} \mathrm{O}$ with no free acid, and analytically determined $\mathrm{HNO}_{3}$ solution ( $1 \%$ error) yields the reproducible results which are shown in Fig. 3. We have made no attempt to measure the acid content of the solutions after mixing because the uncertainties in the number of actual protons produced during $\mathrm{Pu}(\mathrm{IV})$ hydrolysis would exceed those from a calculation that assumes simple reaction steps.

The complex shape of the curves is the most striking feature of Fig. 3. Qualitatively, these curves describe a polymer reaction that starts very slowly and then accelerates to a steady rate which is fairly constant until about $20 \%$ of the plutonium has reacted. The rate decreases when a major portion of the reagent has been consumed or when other influences (to be discussed later) have begun to dominate.

\subsection{Induction Period}

Although it has not been recognized in the previous Pu(IV) polymer studies, the occurrence of an induction period is not unusual when hydrous polymers aggregate (i.e., polymerize). The aggregation of silicic acid, $\mathrm{H}_{4} \mathrm{SiO}_{4}$ [also written as $\mathrm{Si}(\mathrm{OH})_{4}$ ], has been found to experience induction periods that last up to several hundred minutes. 12 The induction period decreases with increasing concentrations of $\mathrm{Si}(\mathrm{OH})_{4}$ and impurity ions (e.g., $\mathrm{NaCl}$ ). As a result of such an induction phenomenon, theoretical analyses of these "condensation" 
mechanisms have been divided into two separate stages - nucleation and growth. The nucleation stage is much like that experienced in ordinary crystal precipitation processes in which the formation of crystallite sites is dependent on such parameters as supersaturation and impurities.

The induction period data that lend themselves to quantitative treatment in the other systems are those obtained from buffered solutions (i.e., fixed $\mathrm{pH}$ ) and from simple reaction mechanisms (i.e., those occurring between monomeric as opposed to mixed aggregate distributions of species).12 Since neither of these conditions has been met in any of the $\mathrm{Pu}(\mathrm{IV})$ polymerization work and also since redox reactions [e.g., disproportionation of $\mathrm{Pu}(\mathrm{IV})$ ] add considerably to the complexity of the plutonium situation, it is prudent to describe only qualitative features of $\mathrm{Pu}(\mathrm{IV})$ polymer kinetics at this time. For the $50^{\circ} \mathrm{C} \mathrm{Pu}(\mathrm{IV})$ polymerization experiments as shown in Fig. 3 , the induction period is most pronounced at $0.13 \mathrm{M} \mathrm{HNO}_{3}$. The rate of polymerization at lower acid concentrations is too rapid to show any appreciable induction effect, and at higher makeup acids, the entire process of both nucleation and growth is so long that the experiment never progressed far into the growth stage.

\section{4 Urany 1 Nitrate Effect}

One major objective of this work was to assess the effect of uranyl nitrate on the polymerization reaction. Because co-processing is currently the acceptable means of reprocessing spent nuclear fuel, a large amount of uranium will always accompany the plutonium; therefore, its effect on the plutonium chemistry must be fully understood. Much uncertainty exists about the effect of $\mathrm{UO}_{2}\left(\mathrm{NO}_{3}\right)_{2}$ on the formation rate of $\mathrm{Pu}(\mathrm{IV})$ polymer since the solute will supply nitrate ions which could (1) complex with Pu(IV) and stabilize it with respect to hydrolysis and polymerization or (2) through complexation with $\mathrm{Pu}(\mathrm{IV})$, shift the disproportionation equilibrium,

$$
3 \mathrm{Pu}^{4+}+2 \mathrm{H}_{2} \mathrm{O} \underset{\leftarrow}{2} \mathrm{Pu}^{3+}+\mathrm{PuO}_{2}^{2+}+4 \mathrm{H}^{+},
$$

to the left, thereby decreasing the real acid concentration of the solution and causing a corresponding increase in the rate of hydrolysis and polymerization. Furthermore, the uranyl ion itself could have 
some effect on the Pu(IV) polymerization chemistry, but so little is known about these interactions that any predictions on the result would be entirely speculative.

Therefore, experiments were designed to resolve the uncertainties outlined above. The focus of attention was on $0.05 \underline{\mathrm{M}} \mathrm{Pu}(\mathrm{IV})$ solutions at $50^{\circ} \mathrm{C}$ both with and without $\mathrm{UO}_{2}\left(\mathrm{NO}_{3}\right)_{2}$. Experiments were performed on several solutions which differed in makeup $\left[\mathrm{HNO}_{3}\right]$ by spectrophotometrically monitoring the concentration of polymer as a function of time. Figure 4 illustrates the results of comparative studies at $50^{\circ} \mathrm{C}$ between $0.05 \mathrm{M}$ solutions containing $0.5 \mathrm{M} \mathrm{UO}_{2}{ }^{2+}$ (solid lines) and those containing no added solutes (dashed lines). In all cases, the addition of $\mathrm{UO}_{2}\left(\mathrm{NO}_{3}\right)_{2}$ reduced the rate of polymer formation by at least $30 \%$. Note that the apparent anomaly in the $0.11 \mathrm{M}$ $\mathrm{HNO}_{3}$ experiment is due to the unexplainable absence of an induction period for the experiment containing $0.5 \mathrm{M} \mathrm{UO}_{2}\left(\mathrm{NO}_{3}\right)_{2}$ and results in a temporarily faster average rate of polymer growth. Several repetitions of the $0.11 \mathrm{M} \mathrm{HNO}_{3}$ experiment (see Fig. 6 in this report) subsequently established the induction period and polymer formation rates that were consistent with the other acid concentrations. The anomaly is included in these data to demonstrate that such nucleation phenomena are often sensitive to apparently insignificant variables, which are not always entirely controllable.

Figure 5 demonstrates that the magnitude of the uranyl solute effect is proportional to its concentration. It must be admitted that the apparent effect is not especially great since the uranyl ion must be present in large amounts relative to the [Pu] (e.g., a 10:1 ratio in these experiments). Nevertheless, this does represent a condition like that found in most fuel reprocessing operations.

In order to specify the nature of the uranyl effect, it was necessary to compare it with that observed for similar additions of $\mathrm{NaNO}_{3}$ and $\mathrm{Ca}\left(\mathrm{NO}_{3}\right)_{2}$. The influence of these solutes on the rate of polymer formation is compared in Fig. 6 with previous results. The $1 \mathrm{M} \mathrm{NaNO}_{3}$ was first used to test the effect of a solute with identical $\mathrm{NO}_{3}{ }^{-}$concentration; later the $0.5 \mathrm{M} \mathrm{Ca}\left(\mathrm{NO}_{3}\right)_{2}$ was used to demonstrate that the difference in the ionic strength was not a factor in the 


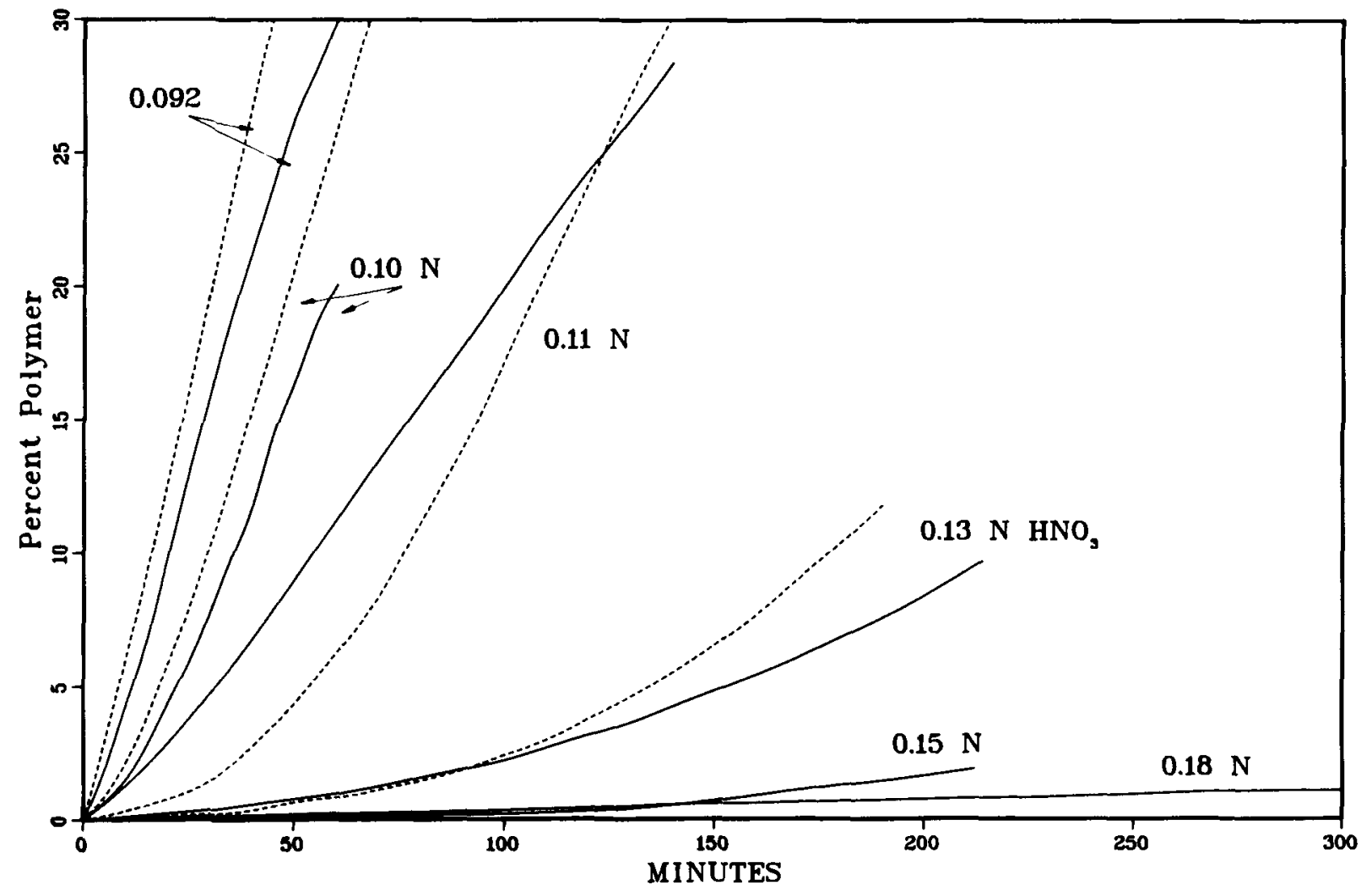

Fig. 4. Percent Pu(IV) polymer as a function of time for $0.05 \mathrm{M}$ $\mathrm{Pu}$ solutions at $50^{\circ} \mathrm{C}$. Solutions containing $0.5 \mathrm{M} \mathrm{UO}_{2}\left(\mathrm{NO}_{3}\right)_{2}$ (solid lines) are compared with those containing no added solutes (dashed lines). Nitric acid concentrations for solutions are indicated on the figure. 


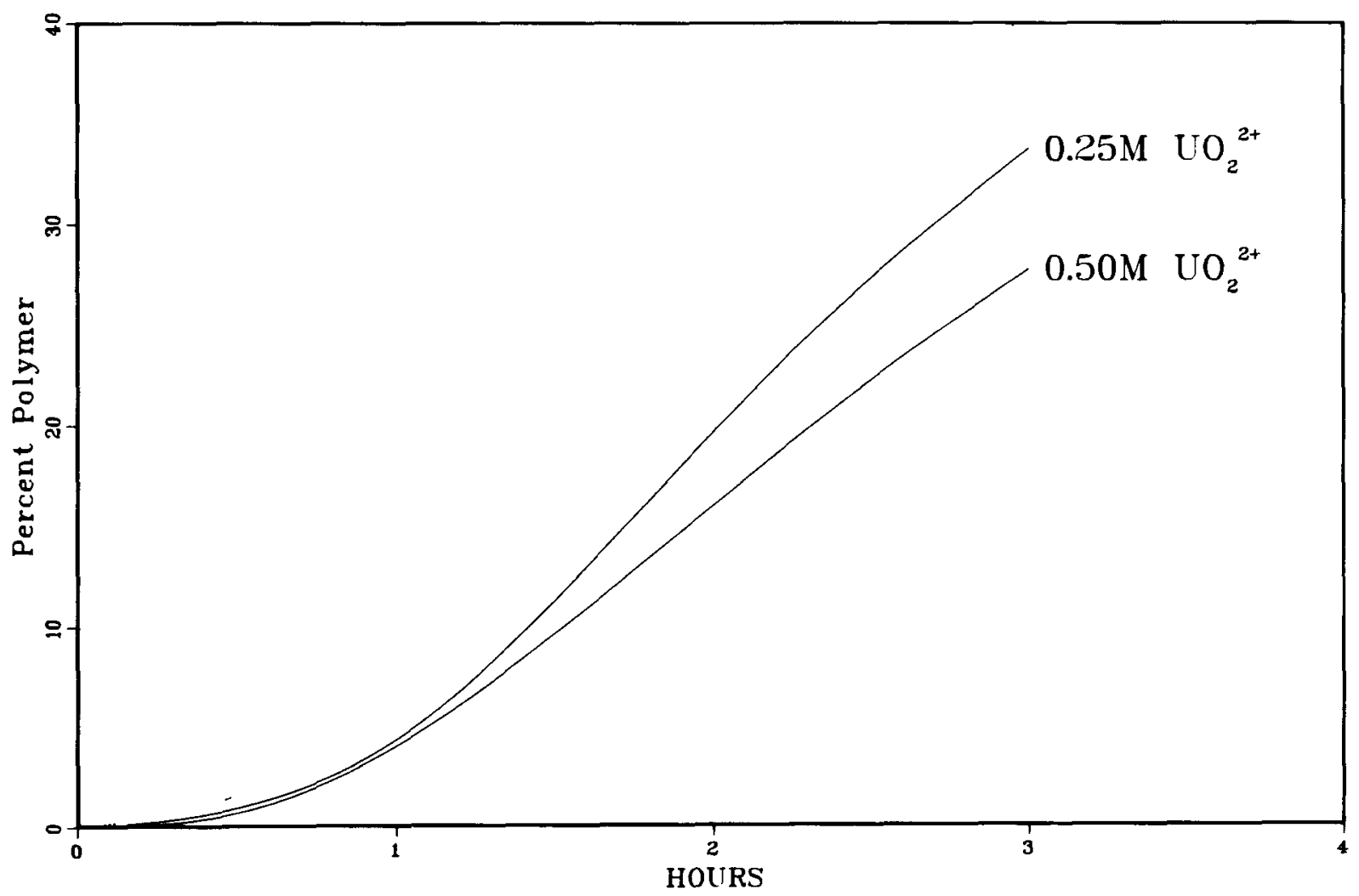

Fig. 5. Effect of $\mathrm{UO}_{2}\left(\mathrm{NO}_{3}\right)_{2}$ solute concentration on $\mathrm{Pu}(\mathrm{IV})$ polymerization rate (solid lines) compared with sample containing no added uranyl solute (dotted line). All samples were run at $50^{\circ} \mathrm{C}$ and in 0.11 $\underline{\mathrm{M}} \mathrm{HNO}_{3}$. 
IRNIL-ONG $79-20593$

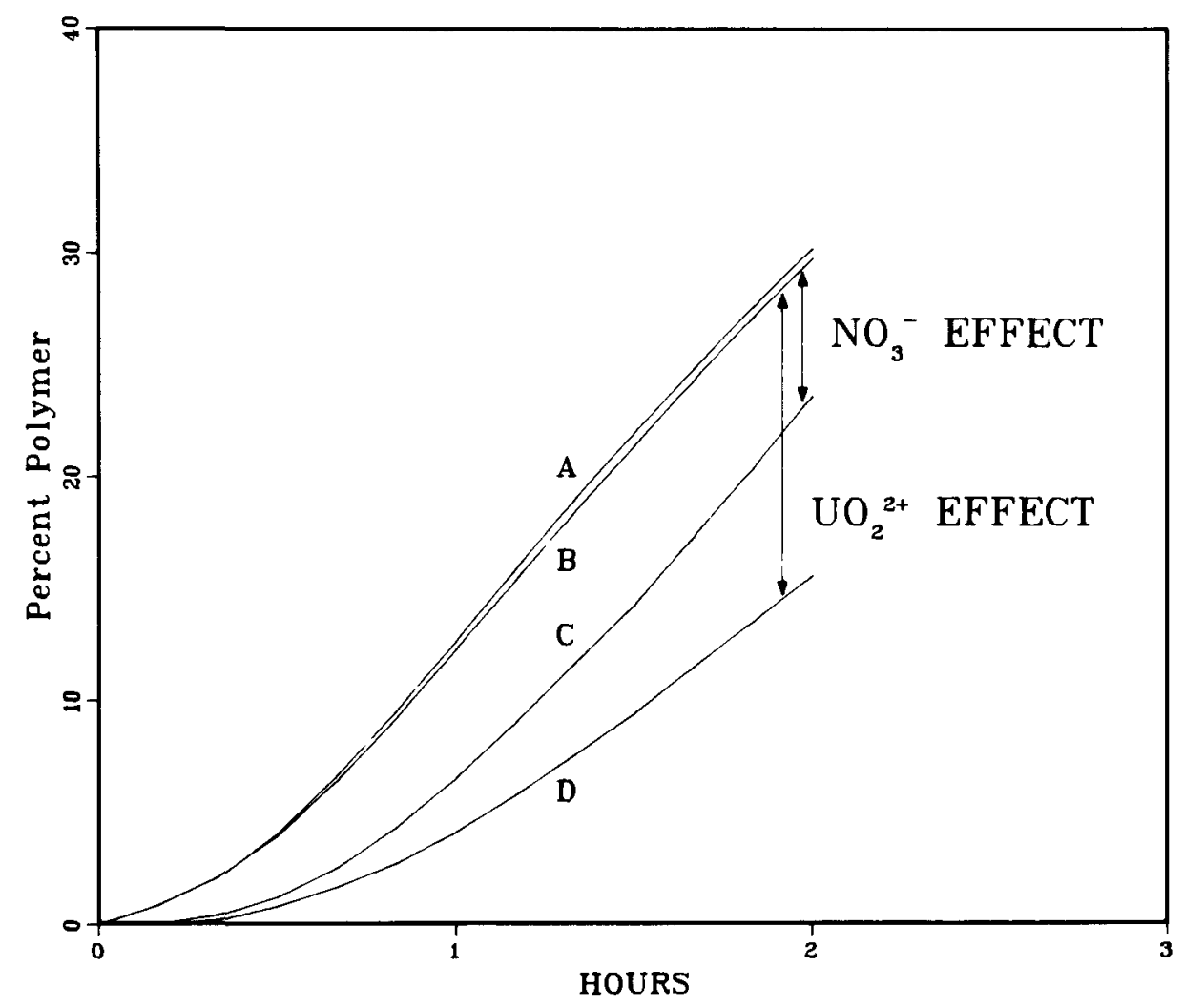

Fig. 6. Comparison of rates of $\mathrm{Pu}(\mathrm{IV})$ polymer formation for 0.05

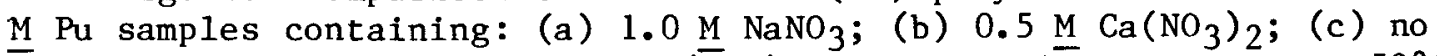
added solute; and (d) $0.05 \underline{\mathrm{M} \mathrm{UO}}{ }_{2}\left(\overline{\mathrm{NO}}_{3}\right)_{2} \cdot \mathrm{All}$ samples were run at $50^{\circ} \mathrm{C}$ and in $0.11 \mathrm{M} \mathrm{HNO}_{3}$. 
measured rates. In similar experiments at $0.072 \mathrm{M} \mathrm{HNO}_{3}$, the $\mathrm{Pu}(\mathrm{IV})$ disproportionation equilibrium shifted far to the left, equivalent to that seen for the uranyl additions (Table 1). Both of these solutes demonstrate the $\mathrm{NO}_{3}$ - effect on the $\mathrm{Pu}(\mathrm{IV})$ hydrolysis and polymerization reactions, which is believed to be the same $\mathrm{NO}_{3}^{-}$effect that occurs with $\mathrm{UO}_{2}\left(\mathrm{NO}_{3}\right)_{2}$ since the shift of the disproportionation equilibrium is the same. The addition of $\mathrm{UO}_{2}\left(\mathrm{NO}_{3}\right)_{2}$, however, produces the opposite overall effect on the $\mathrm{Pu}(\mathrm{IV})$ polymerization reaction that is, the rate is reduced, thereby indicating that the urany 1 ion itself is involved in the polymerization.

Since the uranyl ion interferes with the $\mathrm{Pu}(\mathrm{IV})$ polymerization, we could expect it to attach to active sites in the polymer (e.g., $\mathrm{OH}$ groups) which otherwise would bridge the hydrous polymer network together. 13 The uranyl ion should then block the further attachment of other $\mathrm{Pu}(\mathrm{IV})$ groups to the network and function, in effect, as a chain* termination unit. The $\mathrm{Pu}(\mathrm{IV})$ hydrous polymer that does form should consist of much smaller polymeric aggregates (than are found in pure plutonium systems) and should contain measurable amounts of bound uranyl ion.

It would be reasonable to assume that (1) if uranyl ion were present during the $\mathrm{Pu}(\mathrm{IV})$ hydrolysis and aggregation reactions, measurable amounts of this ion should be attached to the polymer network, and (2) if uranyl ion were added after the $\mathrm{Pu}(\mathrm{IV})$ hydrolysis and aggregation reactions, the uranyl ion could attach only to the outer surface of the $\mathrm{Pu}(\mathrm{IV})$ polymer species (i.e., sol), if at all. Several successful attempts were made to compare the amount of uranyl ion taken up by the Pu(IV) hydrous polymer during the polymerization process with that taken up by $\mathrm{Pu}$ (IV) polymer after the aggregation had been completed. (See Sect. 3 for details of this procedure.) In all cases the uranium content of the plutonium polymer that had formed in the presence of $\mathrm{UO}_{2}{ }^{2+}$ was greater $(0.37 \%)$ than that to which $\mathrm{UO}_{2}{ }^{2+}$ had been added after the polymer had formed (0.12\%).

The one restraining consideration that must be realized is that the $\mathrm{UO}_{2}{ }^{2+}$ could merely have been occluded by the growing $\mathrm{Pu}(\mathrm{IV})$ polymer and is not bound in any way to the network which trapped it.

*"Chain" is used in this context to denote chain reaction and not the structure of the polymer, which is understood to be a threedimensional network. 
Table 1. Comparison of disproportionation at $22^{\circ} \mathrm{C}$ for $0.05 \underline{\mathrm{M}} \mathrm{Pu}$ in $0.072 \underline{\mathrm{M}} \mathrm{HNO}_{3}$ polymer runs containing various solutes

\begin{tabular}{|c|c|c|c|c|c|c|c|c|}
\hline \multirow[b]{2}{*}{$\begin{array}{l}\text { Solute in } \\
\text { polymer run }\end{array}$} & \multicolumn{2}{|c|}{$\mathrm{Pu}($ III $)$} & \multicolumn{2}{|c|}{$\mathrm{Pu}(\mathrm{IV})$} & \multicolumn{2}{|c|}{$\mathrm{Pu}(\mathrm{V})$} & \multicolumn{2}{|c|}{$\mathrm{Pu}(\mathrm{VI})$} \\
\hline & $\begin{array}{l}\text { Absorbance } \\
\text { at } 600 \mathrm{~nm}^{\alpha}\end{array}$ & $\begin{array}{l}\text { Concentration } b \\
(\underline{M})\end{array}$ & $\begin{array}{l}\text { Absorbance } \\
\text { at } 476 \mathrm{~nm}^{\alpha}\end{array}$ & $\begin{array}{l}\text { Concentration } \\
(\mathrm{M})\end{array}$ & $\begin{array}{l}\text { Absorbance } \\
\text { at } 1130 \mathrm{~nm}\end{array}$ & $\begin{array}{c}\text { Concentration } b \\
\text { (M) }\end{array}$ & $\begin{array}{l}\text { Absorbance } \\
\text { at } 951 \mathrm{~nm}^{\circ}\end{array}$ & $\begin{array}{c}\text { Concentration } b \\
\text { (M) }\end{array}$ \\
\hline $0.5 \mathrm{M} \mathrm{Ca}\left(\mathrm{NO}_{3}\right)_{2}$ & 0.263 & 0.012 & 1.089 & 0.026 & 0.246 & 0.005 & 0.089 & 0.003 \\
\hline No added solute & 0.419 & 0.024 & 0.509 & 0.020 & 0.298 & 0.003 & 0.119 & 0.007 \\
\hline $0.5 \underline{\mathrm{M} \mathrm{UO}}{ }_{2}\left(\mathrm{NO}_{3}\right)_{2}$ & 0.239 & 0.010 & 1.171 & 0.027 & 0.240 & 0.005 & 0.079 & 0.002 \\
\hline
\end{tabular}

a Absorbance values at indicated wavelengths where respective plutonium lonic species are dominant.

${ }^{b}$ Concentrations were calculated using best avallable molar extinction coefficients in solution of simultaneous equations. 
A practical test of this possibility would be to examine the infrared and Raman spectra of the polymer containing the uranyl ion to determine if the spectrum of $\mathrm{UO}_{2}{ }^{2+}$, and hence its chemical bonding, is different from that of the free ion. This aspect has been confirmed in a separate spectroscopic investigation of Th(IV) hydrolysis reactions and will be extended to $\mathrm{Pu}(\mathrm{IV})$ hydrolysis reactions in the near future.14 We have concluded meanwhile that the uranyl ion most probably retards the rate of $\mathrm{Pu}(\mathrm{IV})$ hydrous polymer aggregation (polymerization) by a process whereby $\mathrm{UO}_{2}{ }^{2+}$ attaches to hydroxy1 groups on $\mathrm{Pu}(\mathrm{IV})$ and thereby prevents the attachment of other $\mathrm{Pu}$ (IV) groups to these sites. The structure of the Pu(IV)-U(VI) entity is expected to be similar to that reported by Aberg $^{15}$ for the di-uranate species in $\left(\mathrm{UO}_{2}\right)_{2}(\mathrm{OH})_{2} \mathrm{Cl}_{2} \cdot 4 \mathrm{H}_{2} \mathrm{O}$.

The extent of the $\mathrm{UO}_{2}{ }^{2+}$ interaction is illustrated in Fig. 6 by the vertical bar marked " $\mathrm{UO}_{2}{ }^{2+}$." The measured net effect as indicated by the difference in observed rates for samples run with and without $\mathrm{UO}_{2}\left(\mathrm{NO}_{3}\right)_{2}$ additions is not as great; if one accepts that the nitrate ion effect for any of the three solutes is as indicated by " $\mathrm{NO}_{3}{ }^{-}$" on the figure, then the uranyl effect alone is quite large. These data show that the $\mathrm{NO}_{3}{ }^{-}, \mathrm{UO}_{2}{ }^{2+}$, and net effects alter the reference polymerization rate by $+30,-65$, and $-35 \%$ respectively.

\subsection{Reproducibility of Data}

Most researchers who have had experience with plutonium polymer chemistry are aware of the difficulty in obtaining reproducible results for the polymerization reactions. Our experiences in this regard have forced us to test the precision of the data which is presented in Figs. 3 and 4 by repeating the experiment with a variety of preparative approaches. These studies have revealed several factors previously anticipated in most other plutonium polymer studies but never before evaluated quantitatively.

Two major sources of error are usually anticipated: (1) uncertainty in the actual acid content of the plutonium reagent, which will exist when polymer rates from different starting reagents are compared and 
(2) differences in dilution procedures, which will lead to unintentionally initiated hydrolysis reactions. Most reports have implied that "accurate" acid determinations and "careful" dilutions of stock solutions were made and therefore these obvious sources of error need no further attention. Without further testing, however, neither the reader nor the researcher can evaluate the limitations of these assumptions. We have sought to test these assumptions in the following manner.

The reproducibility of the previously discussed data is shown in Fig. 7. As long as the same plutonium stock reagents were used along with the same dilution procedure, a satisfactory reproduction of the data was achieved (cf., solid lines). But when different stock reagents were taken, we were not able to obtain the same results (cf., dashed line using $1.5 \mathrm{M}$ plutonium stock solution).

Much attention was consequently directed to establishing the accuracy of analytically determined acid values. By successively diluting a nominal $1.40 \underline{\mathrm{M} u}-0.75 \underline{\mathrm{M}} \mathrm{HNO}_{3}$ stock solution with $1.0 \mathrm{M}$ $\mathrm{HNO}_{3}$ followed by acid determination, it was learned that the unaltered iodate method 10 failed to give accurate acid values when the [Pu] was greater than $0.1 \mathrm{M}$. The error in the determination increased with the plutonium concentration in accordance with previous observations. 11 Never has any systematic study of acid analyses for Pu(IV) solutions greater than $0.1 \mathrm{M}$ been reported, and the assumption that methods suitable for less than $0.1 \mathrm{M}$ Pu(IV) would be satisfactory for higher concentrations is a major fallacy in some plutonium work. Since the error in the acid analysis was always in the positive direction, hydrolysis of the $\mathrm{Pu}$ (IV) is suspected during iodate precipitation from a medium adjusted to $\mathrm{pH}$ 4.3. Further acidification of the iodate medium as described in Sect. 3 minimized the problem to a degree acceptable for this work, but further analytical development in this area is clearly needed in order to handle the recurring need for free acid values in solutions greater than $0.1 \mathrm{M} \mathrm{Pu}$. (Our experience with the oxalate method ${ }^{10}$ through our analytical department indicates that the oxalate procedure is even more susceptible to error since titrations of the oxalate-complexed $\mathrm{Pu}(\mathrm{IV})$ are normally carried to a $\mathrm{pH}$ at which the complex can dissociate.) 


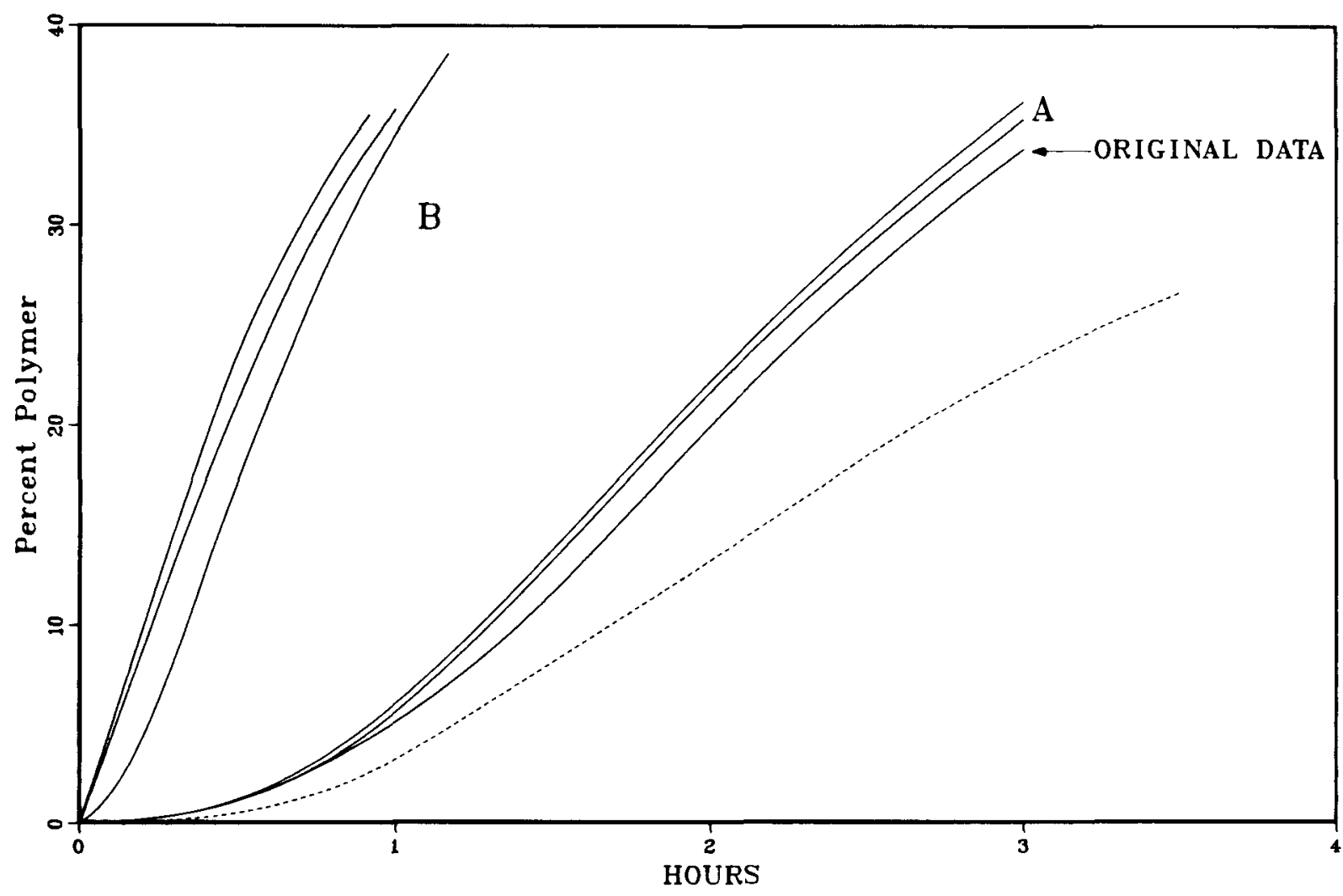

Fig. 7. Reproducibility of $\mathrm{Pu}$ (IV) polymer formation data, comparing original data with rechecks using: (a) the same starting stock solution that was $0.35 \mathrm{M} \mathrm{Pu(IV)}$ and (b) a more highly concentrated, $1.25 \mathrm{M} \mathrm{Pu}(\mathrm{IV})$, stock solution. Dashed line shows a solution made from same stock as used in the "original data" and (a) cases, but with 0.5 $\mathrm{M} \mathrm{UO}_{2}\left(\mathrm{NO}_{3}\right)_{2}$ added, for comparison. All solutions were run at $50^{\circ} \mathrm{C}$ and were nominally (see text) $0.11 \mathrm{M} \mathrm{HNO}_{3}$. 
After modifying the iodate precipitation method, acid values for all stock solutions were remeasured and the corrected concentrations used to recalculate the makeup acid concentrations for each experiment. These are the values that appear on the curves in the figures. As long as the same dilution procedure was used, it was possible to obtain agreement in polymerization rates for any plutonium reagent solution. When different dilution procedures were used, the inconsistent rates again appeared.

\subsection{Dilution Effects}

Another frequently cited problem in polymer reactions is the unintentional initiation of polymerization that occurs when lessacidic solutions are mixed with Pu(IV) solutions. Although it is widely known that these dilution problems can occur under certain extreme cases [e.g., distilled water mixed into low-acid $\left(<0.2 \underline{\mathrm{M}} \mathrm{H}^{+}\right)$ $\mathrm{Pu}$ solution], experimentalists of ten mix low-acid solutions into plutonium solutions by some means that they believe does not initiate any polymer reactions. For example, "slow additions of diluent with vigorous stirring" are often cited. The following discussion will demonstrate that even these precautions are most often too relaxed and therefore all previous polymerization experiments probably suffered greatly from irregularities caused by dilution effects.

The initial approach taken in this work was similar to that used previously. We began with local stock solutions that were approximately $0.35 \underline{\mathrm{M} u}$ and $0.70 \mathrm{M} \mathrm{HNO}_{3}$, sometimes followed by the addition of other reagent solutions [e.g., $\left.\mathrm{UO}_{2}\left(\mathrm{NO}_{3}\right)_{2}\right]$ and then diluted to the final concentration and volume with either acid or distilled water. The additions were made as slowly and with as much stirring as possible and therefore appeared to fulfill those criteria for "carefully prepared" solutions. These data appear in Figs. 4 through 7; as long as the procedure is repeated with reasonable diligence, the precision demonstrated in Fig. 7 is easy to achieve.

During our efforts to eliminate the discrepancies between experiments prepared from different stock solutions (Sect. 4.5), we prepared crystalline $\mathrm{Pu}\left(\mathrm{NO}_{3}\right)_{4} \cdot 3.6 \mathrm{H}_{2} \mathrm{O}$ and dissolved it directly into an $\mathrm{HNO}_{3}$ solution that was at (or very near, depending on the occluded 
acid in the crystals) the concentration sought for the polymerization study. Obviously, these solutions must be the least subject to unintentional polymer initiation due to dilution procedure, and therefore, the "crystalline stock" experiments are believed to represent "ideal" polymerization rates otherwise not seen by previous researchers. In addition, we have made "pseudo stock" solutions by dissolving crystalline stock in nitric acid to make a stock solution of $0.35 \mathrm{M} \mathrm{Pu}$ and $0.7 \mathrm{M} \mathrm{HNO}_{3}$ (like that of the originally supplied material); this stock behaved just as the other plutonium stock solutions, which demonstrates that the dilution procedure was the factor that determined the measured rate of polymerization.

These experiments on dilution effects are still under study and will be presented in detail in a later report.

\section{7 Plutonium Concentration Effect}

The rate of polymer formation has been shown to be first order in $[\mathrm{Pu}(\mathrm{IV})]$ and inverse second order in $\left[\mathrm{H}^{+}\right] ;^{5}$ that is,

$$
\frac{\mathrm{di}[\text { polymer }]}{\mathrm{dt}}=\mathrm{k}[\mathrm{Pu}(\mathrm{IV})]\left[\mathrm{H}^{+}\right]^{-2} \text {. }
$$

If we assume initial conditions ( $<10$ to $20 \%$ reaction) so that the $[\mathrm{Pu}(\mathrm{IV})]$ is approximately equal to $\left[\mathrm{Pu}_{\mathrm{T}}\right]$ (or some constant fraction of this amount, if disproportionation occurs), we can divide Eq. (2) by $[\mathrm{Pu}(\mathrm{IV})]$ and replace if by $\left[\mathrm{Pu}_{\mathrm{T}}\right]$. Thus,

$$
\frac{\mathrm{d}[\text { polymer }]}{\mathrm{dt}\left[\mathrm{Pu}_{\mathrm{T}}\right]}=\left(\frac{1}{[\mathrm{Pu}(\mathrm{IV})]}\right)\left(\frac{\mathrm{d}[\mathrm{polymer}]}{\mathrm{dt}}\right)=\mathrm{k}\left[\mathrm{H}^{+}\right]^{-2} .
$$

Furthermore, at initial conditions just after the disproportionation equilibrium has been established and little polymerization has occurred, the acid concentration can also be assumed to be constant, and we can write $\mathrm{k}^{\prime}=\mathrm{k}\left[\mathrm{H}^{+}\right]^{-2}$.

If the rate of polymerization is first order in $[\mathrm{Pu}(\mathrm{IV})]$, then a plot of the percent polymer as a function of time should not vary as the initial $[\mathrm{Pu}(\mathrm{IV})]$ is varied for a constant $\left[\mathrm{H}^{+}\right]$. (These will henceforth be identified as "percentage rates.") We sought to verify this in the early stages of our work by measuring rates of polymer 
formation at concentrations greater than that of our $0.05 \underline{M}$ reference solution - namely, at 0.125 and $0.5 \mathrm{M}$. Progressively faster percentage rates were always found in both cases, but these results were somewhat marred by lingering uncertainties about the acid values of the starting reagent solutions.

It was first necessary to deal with the questions of acid analyses and dilution effects before addressing questions related to the $\mathrm{Pu}$ (IV) concentration parameter; therefore, the resolution of these two questions has preceded this section. It was then realized that the very high, $0.5 \underline{\mathrm{M}}\left[\mathrm{Pu}_{\mathrm{T}}\right]$, solutions could not be prepared because the amount of acid occluded in the crystalline material was so great that we could not dissolve this material in aqueous solvent and arrive at a suitably low total acid concentration to begin the experiment. (For example, if the occluded $\mathrm{H}^{+} / \mathrm{Pu}$ was 0.3 , then a $0.5 \mathrm{M}$ Pu solution made by dilution with water would be $0.15 \mathrm{M} \mathrm{HNO}_{3}$, and we were aware that dilution with solutions less acidic than $0.13 \mathrm{M}$ would prematurely initiate the polymerization reaction.)

Experiments have been run using crystalline Pu(IV) stock for both 0.05 and $0.125 \mathrm{M} \mathrm{Pu}$ at 0.17 and $0.20 \mathrm{~N}$ makeup $\left[\mathrm{HNO}_{3}\right]$, and these results are presented in Table 2 and Fig. 8. The percentages presented in the table were calculated from measured absorbances using $50^{\circ} \mathrm{C}$ molar extinction coefficient values for the plutonium species. (See Appendix for these values.) "Real" acid concentrations were determined from the following expression taken from Eq. (1) of ref. 5:

$$
\left[\mathrm{H}^{+}\right]=\left[\mathrm{H}^{+}\right]_{0}+4([\mathrm{Pu}(\mathrm{V})]+[\mathrm{Pu}(\mathrm{VI})])+3.6[\mathrm{Pu}(\text { poly })]
$$

In spite of some limitations in these calculations, they show that

1. The $\mathrm{Pu}(\mathrm{IV})$ and $\mathrm{H}^{+}$concentrations remain very constant throughout the initial stages of the polymerization.

2. $\mathrm{Pu}(\mathrm{IV})$ is more disproportionated at $\left[\mathrm{Pu}_{\mathrm{T}}\right]=0.05 \mathrm{M}$ than at $\left[\mathrm{Pu}_{\mathrm{T}}\right]=0.125$ - as would be expected.

3. The real $\left[\mathrm{H}^{+}\right]$for $\left[\mathrm{Pu}_{\mathrm{T}}\right]=0.125 \mathrm{M}$ is greater than or equal to that for $\left[\mathrm{Pu}_{\mathrm{T}}\right]=0.05 \underline{\mathrm{M}}$ with the same makeup $\left[\mathrm{HNO}_{3}\right]$. 
Table 2. Distribution of plutonium species and real $\left[\mathrm{H}^{+}\right]$during polymerization runs at $50^{\circ} \mathrm{C}$ for the makeup $\left[\mathrm{HNO}_{3}\right]$ and $\left[\mathrm{Pu}_{\mathrm{T}}\right]$ indicated

\begin{tabular}{|c|c|c|c|c|c|c|c|c|c|}
\hline \multirow[b]{2}{*}{ Sample No. } & \multirow[b]{2}{*}{$\begin{array}{r}\text { Time } \\
(\mathrm{h})\end{array}$} & \multicolumn{3}{|c|}{ Concentration $(\mathrm{mol} / \mathrm{L})$} & \multicolumn{5}{|c|}{ Percentage of total plutonium } \\
\hline & & $\begin{array}{l}\mathrm{HNO}_{3} \\
\text { makeup }\end{array}$ & $\mathrm{H}^{+}{ }_{\text {actual }}{ }^{a}$ & $\begin{array}{c}\mathrm{Pu} \\
\text { total }\end{array}$ & $\overline{\mathrm{Pu}(\mathrm{III})}$ & $\mathrm{Pu}(\mathrm{IV})$ & $\mathrm{Pu}(\mathrm{V})$ & $\mathrm{Pu}(\mathrm{VI})$ & Polymer \\
\hline 123 & $\begin{array}{l}0.43 \\
1.83 \\
2.83 \\
4.13\end{array}$ & $\begin{array}{l}0.17 \\
0.17 \\
0.17 \\
0.17\end{array}$ & $\begin{array}{l}0.31 \\
0.31 \\
0.32 \\
0.34\end{array}$ & $\begin{array}{l}0.125 \\
0.125 \\
0.125 \\
0.125\end{array}$ & $\begin{array}{l}34.6 \\
33.8 \\
30.6 \\
27.5\end{array}$ & $\begin{array}{l}35.0 \\
37.5 \\
37.7 \\
36.9\end{array}$ & $\begin{array}{r}11.8 \\
7.1 \\
4.8 \\
1.6\end{array}$ & $\begin{array}{l}16.9 \\
15.7 \\
13.7 \\
12.3\end{array}$ & $\begin{array}{r}1.7 \\
6.0 \\
13.3 \\
21.7\end{array}$ \\
\hline 127 & $\begin{array}{r}0.5 \\
17.1\end{array}$ & $\begin{array}{l}0.17 \\
0.17\end{array}$ & $\begin{array}{l}0.24 \\
0.25\end{array}$ & $\begin{array}{l}0.050 \\
0.050\end{array}$ & $\begin{array}{l}43.0 \\
36.3\end{array}$ & $\begin{array}{l}20.2 \\
22.3\end{array}$ & $\begin{array}{r}17.1 \\
6.9\end{array}$ & $\begin{array}{l}19.4 \\
14.8\end{array}$ & $\begin{array}{r}0.3 \\
19.6\end{array}$ \\
\hline 122 & $\begin{array}{l}0.57 \\
2.17 \\
2.46\end{array}$ & $\begin{array}{l}0.17 \\
0.17 \\
0.17\end{array}$ & $\begin{array}{l}0.25 \\
0.24 \\
0.24\end{array}$ & $\begin{array}{l}0.050 \\
0.050 \\
0.050\end{array}$ & $\begin{array}{l}42.8 \\
42.9 \\
42.8\end{array}$ & $\begin{array}{l}18.8 \\
19.9 \\
20.1\end{array}$ & $\begin{array}{l}18.4 \\
16.4 \\
16.3\end{array}$ & $\begin{array}{l}19.4 \\
19.7 \\
19.7\end{array}$ & $\begin{array}{l}0.7 \\
1.0 \\
1.1\end{array}$ \\
\hline 119 & $\begin{array}{l}0.45 \\
1.75 \\
3.32\end{array}$ & $\begin{array}{l}0.20 \\
0.20 \\
0.20\end{array}$ & $\begin{array}{l}0.33 \\
0.33 \\
0.32\end{array}$ & $\begin{array}{l}0.125 \\
0.125 \\
0.125\end{array}$ & $\begin{array}{l}32.6 \\
33.1 \\
33.0\end{array}$ & $\begin{array}{l}42.2 \\
41.5 \\
42.8\end{array}$ & $\begin{array}{l}9.3 \\
8.7 \\
5.1\end{array}$ & $\begin{array}{l}15.0 \\
15.2 \\
14.8\end{array}$ & $\begin{array}{l}0.9 \\
1.4 \\
4.3\end{array}$ \\
\hline 120 & $\begin{array}{c}0.57 \\
1.5 \\
2.67 \\
19.7 \\
26.7\end{array}$ & $\begin{array}{l}0.20 \\
0.20 \\
0.20 \\
0.20 \\
0.20\end{array}$ & $\begin{array}{l}0.27 \\
0.27 \\
0.27 \\
0.27 \\
0.27\end{array}$ & $\begin{array}{l}0.050 \\
0.050 \\
0.050 \\
0.050 \\
0.050\end{array}$ & $\begin{array}{l}40.6 \\
40.8 \\
40.9 \\
41.6 \\
41.4\end{array}$ & $\begin{array}{l}23.8 \\
23.6 \\
24.1 \\
25.5 \\
25.8\end{array}$ & $\begin{array}{l}15.9 \\
15.8 \\
15.4 \\
13.1 \\
12.8\end{array}$ & $\begin{array}{l}19.2 \\
19.3 \\
18.9 \\
19.0 \\
18.9\end{array}$ & $\begin{array}{l}0.6 \\
0.6 \\
0.6 \\
0.8 \\
1.1\end{array}$ \\
\hline
\end{tabular}

${ }^{a}\left[\mathrm{H}^{+}\right]$defined in Eq. (5).

$b_{\text {Total }}[\mathrm{Pu}]=\left[\mathrm{Pu}_{\mathrm{T}}\right]$. 


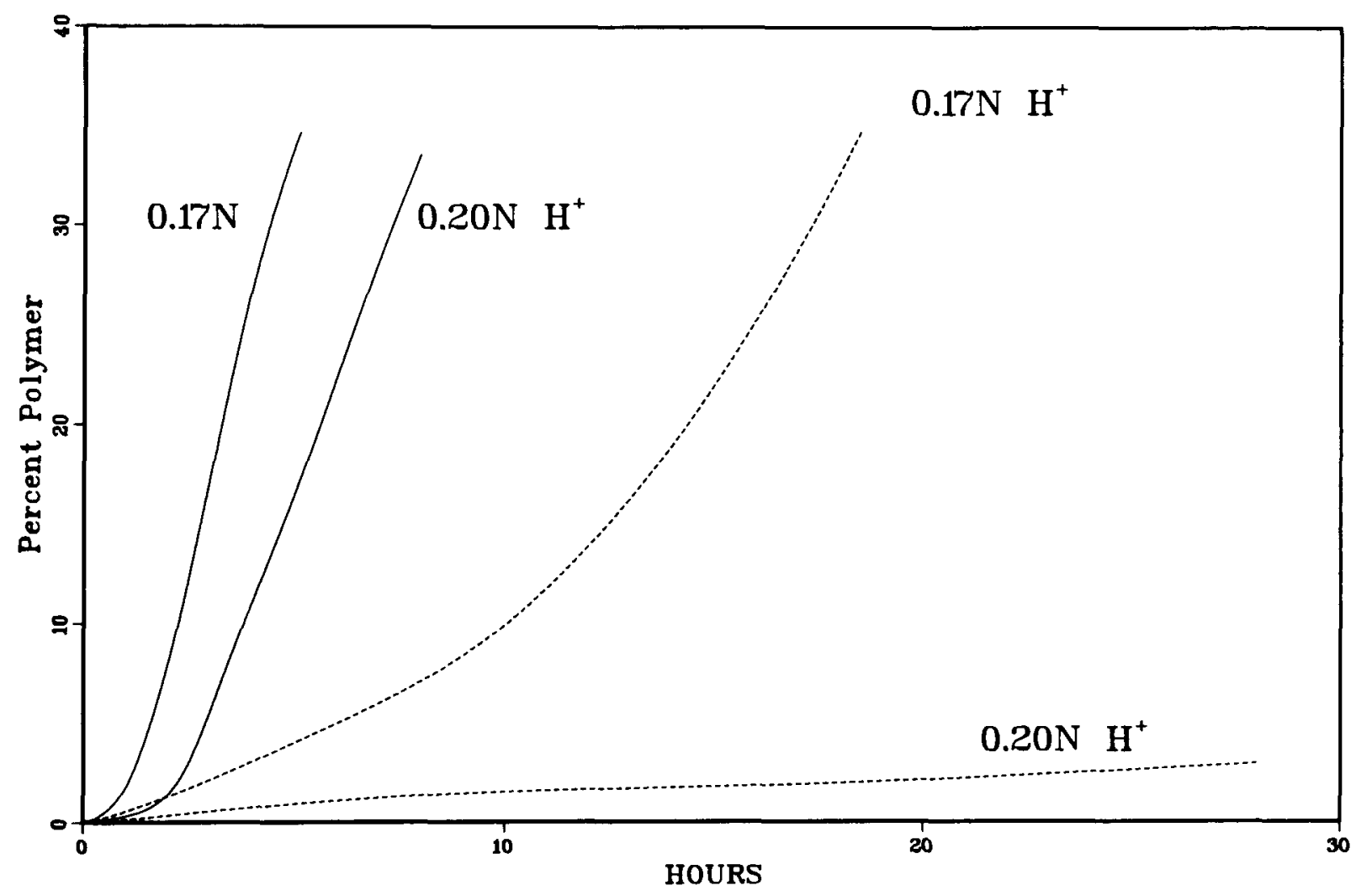

Fig. 8. Effect of $[\mathrm{Pu}(\mathrm{IV})]$ on the rate of polymerization at $50^{\circ} \mathrm{C}$ for two different acid concentrations. Solid lines are for $0.125 \mathrm{M}$ $\mathrm{Pu}(\mathrm{IV})$, and dashed lines are for $0.05 \underline{\mathrm{M}} \mathrm{Pu}(\mathrm{IV})$ solutions. 
The same experiments are presented in Fig. 8 as percent polymer plots over the initial period of the reaction; but these percentages were computed separately (see Sect. 3) since we had observed that the method used to determine the species distribution shown in Table 2 does not yield reliable concentrations for $\mathrm{Pu}(\mathrm{V})$ or polymer. It is clearly evident that the percentage polymer rates are very sensitive to the total [Pu], thus demonstrating that the polymerization reaction is not first order in [Pu(IV)] as was previously suggested. 5

If we rewrite the polymerization rate expression of Eq. (2) for a constant acid composition and an unknown order with respect to $[\mathrm{Pu}(\mathrm{IV})]$, then

$$
\mathrm{d}[\text { polymer }] / \mathrm{dt}=\mathrm{k}[\mathrm{Pu}(\mathrm{IV})]^{\mathrm{n}} \text {. }
$$

A plot of $-\log (d[$ polymer]/dt) versus $\log [\mathrm{Pu}(\mathrm{IV})]$ should yield a line with slope $\underline{n}$. Using the data of Table 2 at $\left[\mathrm{H}^{+}\right]=0.25$ to $0.27 \underline{\mathrm{M}}$ for $[\mathrm{Pu}(\mathrm{IV})]$ and the slopes of the curves in Fig. 8 during the polymer growth stages, we obtain a preliminary value for $\underline{n}=1.5$. More work on the $\mathrm{Pu}(\mathrm{IV})$ concentration effect, with greater effort given to the control of the $\left[\mathrm{H}^{+}\right]$, will be required to more accurately determine the order of the polymerization growth stage reaction.

\section{CONCLUSIONS}

The polymerization reaction of $\mathrm{Pu}$ (IV) hydrolysis products has been shown to proceed through two stages - an induction or nucleation step and a growth period. In many respects, this chemistry is similar to that seen in the silicate system where $\mathrm{Si}(\mathrm{OH})_{4}$ aggregates in a polymeric network. This related work has shown that fundamental kinetic data are possible only through thoroughly controlled experimental parameters (e.g., acid buffered systems), which are not within the scope of the current work. However, future developments may necessitate the adoption of such procedures.

The addition of uranyl nitrate to a plutonium solution retards the polymer formation rate by about $35 \%$ in spite of the rate increase expected from the accompanying nitrate ions of the solute. The effect is believed to be caused by a chain termination process where the uranyl ion is incorporated in the polymer network and thereby blocks further aggregation of plutonium hydrolysis products. A closely 
related fundamental study is currently seeking to establish the validity of this hypothesis.

The demonstration that the rate of percent polymer formation increases with increasing $[\mathrm{Pu}]$ indicates that the kinetic rate expression for this reaction is not first order in [Pu]. Further work is required to refine the order of this reaction.

Much variation in polymer formation rates is often caused by variations in the sample preparation and dilution procedures. The procedure least likely to produce accelerated rates of polymer formation can be achieved by dissolving crystalline plutonium stock material in a solution at the acid concentration intended for the study. Since this represents the ideal dilution procedure, it might never be encountered in a practical operation where direct dilutions of the medium are more prevalent. An exception to this might be encountered in an extraction process if the acid content of the aqueous phase were allowed to decrease very slowly. Further work on the practical impact of dilution phenomena is clearly warranted. 


\section{REFERENCES}

1. D. W. Ockenden and G. A. Welch, J. Chem. Soc. 3358 (1956).

2. K. A. Kraus, Proceedings of International Conference on Peaceful Uses of Atomic Energy, 7, 245 (1956).

3. J. J. Katz and G. T. Seaborg, The Chemistry of the Actinide Elements, John Wiley and Sons, New York, 1957.

4. D. A. Costanzo, R. E. Biggers, and J. T. Bell, J. Inorg. Nucl. Chem. 35, 609 (1973).

5. J. T. Be11, D. A. Costanzo, and R. E. Biggers, J• Inorg. Nucl. Chem. 35, 623 (1 973).

6. J. T. Be11, C. F. Coleman, D. A. Costanzo, and R. E. Biggers, J. Inorg. Nucl. Chem. 35, 629 (1973).

7. A. Brunstad, The Polymerization and Precipitation of Pu(IV) in

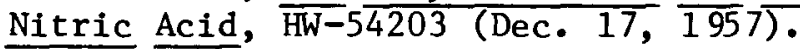

8. V. L. Schuelein, Parameters for Pu Polymer Formation in Nitric Acid, ARH-SA-233 (May 1975).

9. D. A. Costanzo and R. E. Biggers, A Study of the Polymerization, Depolymerization, and Precipitation of Tetravalent Plutonium as Functions of Temperature and Acidity by Spectrophotometric Methods: Preliminary Report, ORNL-TM-585 (July 1, 1963).

10. J. W. Dahlby, G. R. Waterbury, and C. F. Metz, Investigation of Two Methods for Measuring Free Acid in Plutonium Solutions, LA-3876 (Mar. 12, 1968).

11. G. Chottard, Decomposition Thermique du Nitrate d'Urany1 Hexahydrate. Etude des Intermedaires de Cette Decomposition, Thesis, CEA-R $-\overline{3717}$ ( $\overline{\text { Dec. }} \overline{19,1968)}$.

12. W. W. Harvey, M. J. Turner, J. Slaughter, and A. C. Makrides, "Study of Silica Scaling from Geothermal Brines," EIC Corp. Prog. Rep. for March 1976-September 1976, CO0-2607-3, $19 \overline{96 .}$

13. G. L. Johnson and L. M. Toth, Pu(IV) and Th(IV) Hydrous Polymer Chemistry, ORNL/TM-6365 (May 1978).

14. L. M. Toth and G. M. Begun, results to be published.

15. M. Aberg, Acta Chem. Scand. Ser. A, 23, 791 (1969). 
•

- 


\section{Appendix}

MOLAR EXTINCTION COEFFICIENTS FOR PLUTONIUM SPECIES AT $50^{\circ} \mathrm{C}$

These data yield individual species concentrations that equal or exceed the accuracy of previous such determinations. Nevertheless, deficiencies are still apparent when the concentrations are examined with respect to redox balance [e.g., on $\mathrm{Pu}(\mathrm{IV})$ disproportionation], total concentration of species, and presence or quantity of polymer. Realizing these deficiencies, the following $50^{\circ} \mathrm{C}$ molar extinction coefficient matrix, in units of $\mathrm{L} \cdot \mathrm{mol}^{-1} \cdot \mathrm{cm}^{-1}$, was used.

\begin{tabular}{crrrrr}
\hline \multirow{2}{*}{$\begin{array}{c}\text { Wavelength } \\
(\mathrm{nm})\end{array}$} & \multicolumn{5}{c}{ Pu oxidation state (species) } \\
\cline { 2 - 6 } & III & IV & V & VI & Polymer \\
\hline 400 & 5.25 & 23.55 & 3.73 & 9.88 & 150.00 \\
476 & 2.32 & 41.60 & 2.54 & 8.91 & 34.16 \\
600 & 32.21 & 1.95 & 0.29 & 0.92 & 11.83 \\
951 & 1.10 & 1.83 & 1.13 & 20.68 & 4.94 \\
1130 & 10.30 & 5.00 & 16.10 & 0.61 & 5.73 \\
\hline
\end{tabular}


-

0 


\author{
ORNL/TM-7180 \\ Dist. Category UC-86 \\ (Applied)
}

INTERNAL DISTRIBUTION

1. S. M. Babcock

2. J. T. Bell

3. J. E. Bigelow

4. W. D. Bond

5-9. W. D. Burch

10. D. O. Campbe11

11. E. D. Collins

12. D. A. Costanzo

13. R. M. Counce

14. D. J. Crouse

15. K. E. Dodson

16. R. D. Ehrlich

17. M. J. Feldman

18. R. L. Fellows

19-23. H. A. Friedman

24. J. H. Goode

25. J. C. Griess

26. W. S. Groenier

27. B. A. Hannaford

28. A. L. Harkey

29. R. T. Jubin

30. P. R. Kasten

31. M. V. Keigan

32. H. T. Kerr

33. L. J. King

34. J. Q. Kirkman

35. C. E. Lamb

36. R. E. Leuze

37. B. E. Lewis
38. J. C. Mailen

39. A. P. Malinauskas

40. J. L. Marley

41. J. F. Mincey

42. A. D. Mitchell

43. E. L. Nicholson

44. R. E. Norman

45. E. D. North

46-50. M. M. Osborne

51. R. L. Philippone

52. R. H. Powell

53. D. J. Pruett

54. G. L. Ragan

55. A. D. Ryon

56. J. H. Shaffer

57. J. R. Stokely

58. D. W. Swindle

59. 0. K. Tallent

60-64. L. M. Toth

65. W. E. Unger

66. V. C. A. Vaughen

67. M. E. Whatley

68. 0. 0. Yarbro

69-70. Laboratory Records Department

71. Laboratory Records, ORNL R.C.

72. ORNL Patent Section

73. Nuclear Safety Information Center

\title{
EXTERNAL DISTRIBUTION
}

74-75. W. W. Ballard, Nuclear Fuel Cycle Division, Office of Light Water Reactors, DOE, Washington, DC 20545

76. Office of Assistant Manager for Energy Research and Development, DOE-ORO

77-162. Given distribution as shown in TID-4500 under UC-86, Consolidated Fuel Reprocessing Category (applied) 